\title{
The views of undergraduate nursing students on caring for patients with HIV/AIDS
}

\author{
MM Madumo, MCur \\ Department of Nursing Science, University of Limpopo - Medunsa Campus \\ MD Peu, MCur \\ Department of Nursing Science, University of Pretoria
}

\section{Keywords:}

HIV/AIDS, Undergraduate nursing students, Emotions, Antiretroviral therapy delivery, Clinical accompaniment Curriculum innovation

\section{Correspondence address:}

Mrs MD Peu

Department of Nursing Science PO BOX 667

Faculty of Health Care Sciences

University of Pretoria

Pretoria. 0001

Tel: $0123542133 / 0825344245$

Fax: 0123541490

E-mail: mpeu@postillion.up.ac.za

\section{Abstract: Curationis 29(3): 87-96}

A qualitative, exploratory and descriptive study was conducted with the purpose of exploring and describing the views of undergraduate nursing students on caring for HIV/AIDS patients.

The study population consisted of BCur III nursing students studying at the Medical University of Southern Africa (Medunsa). Participants were purposively selected. Focus group interviews were used as a data collection instrument. Guided by a group moderator and responding to a central research question, participants shared their views about caring for HIV/AIDS patients. Tesch's qualitative method of data analysis, as described by Cresswell (1994:155), was used to analyse the data.

Caring for HIV/AIDS patients evoked emotions such as fear, anger and frustration among undergraduate nursing students. Students expressed needs such as the acquisition of knowledge and a reduction in the stigmatisation of patients with HIV/ AIDS, while the data analysis revealed demands such as more intensive clinical accompaniment by lecturers and antiretroviral therapy delivery by government. Suggested solutions included student participation in HIV/AIDS prevention campaigns and the upholding of patients' rights. Curriculum innovation was recommended to improve students' knowledge of HIV/AIDS and to ensure the provision of quality care for these patients.

\section{Opsomming}

' $n$ Kwalitatiewe, eksploratiewe en beskrywende studie is gedoen met die doel om die standpunte van voorgraadse verpleegstudente oor die versorging van MIV/Vigspasiënte te verken en te beskryf.

Die studiepopulasie het bestaan uit BCur Ill-studente van die Mediese Universiteit van Suider-Afrika (Medunsa). Deelnemers is doelbewus geselekteer. Fokusgroeponderhoude is as " $n$ instrument vir data-insameling gebruik. Deelnemers het onder leiding van 'n groepmoderator op 'n sentrale navorsingsvraag gereageer en hulle standpunte oor die verpleging van MIV/Vigs-pasiënte gestel. Tesch se kwalitatiewe metode van data-analise, soos dit deur Cresswell (1994:155) beskryf word, is vir die analisering van data gebruik.

Die verpleging van MIV/Vigs-pasiënte het emosies soos vrees, woede en frustrasie by voorgraadse verpleegstudente gewek. Studente het behoeftes uitgespreek soos die verkryging van kennis en ' $n$ vermindering in die stigmatisasie van pasiënte met MIV/Vigs. Die data-analise het getoon dat eise gestel is soos intensiewer kliniese 
begeleiding deur lektore en antiretroviraleterapielewering deur die regering. Voorgestelde oplossings het studentedeelname aan MIV/Vigsvoorkomingsveldtogte en die handhawing van pasiëntregte ingesluit. Kurrikuluminnovasie is aanbeveel om studente se kennis van MIV/Vigs te verbeter en kwaliteit verpleegsorg aan MIV/Vigs-pasiënte te verseker.

Sleutelterme: MIV/Vigs, Voorgraadse verpleegstudente, Emosies, Antiretroviraleterapielewering, Kliniese begeleiding, Kurrikuluminnovasie

\section{Introduction}

The emergence of the human immunodeficiency virus (HIV) and its resultant syndrome, the acquired immunodeficiency syndrome (AIDS), as public health concern has created ethical and legal healthcare dilemmas, which were previously unheard-of within the healthcare system.

There is growing acknowledgement that many young adults regularly engage in behaviour that puts them at risk of becoming infected with HIV. Considering their ages (usually between 18 and 25 years) and sexual activities, nursing students themselves could be regarded as young adults who are at risk of becoming infected with HIV. Their youthfulness, vulnerability, lack of judgement and obvious lack of adequate knowledge about HIV/AIDS leave nursing students with a feeling of uncertainty when they have to deal with HIV/AIDS patients.

Nursing students enter tertiary education with elementary knowledge of HIV/AIDS - knowledge they have obtained from sources such as primary and secondary education, society, and the media (Serlo \& Aavarinne 1999:468). Often it is expected of these students to care for AIDS patients from the time of entry into nursing practice. All too often they have to care for HIV/AIDS patients even before the condition is discussed in the classroom. These very early experiences of and exposure to caring for patients with HIV/AIDS lead to feelings of fear and anxiety.

\section{Background to and significance of study}

Since HIV was first described in 1983 (more than 21 years ago), millions of people have become infected worldwide. AIDS has become the world's most serious public health concern (Evian 2000:3).

It seems that some countries and communities are more vulnerable to HIV infection than others. Approximately 34.3 million people are infected worldwide, and about $90 \%$ of these infections occurred in developing or poor countries. The hardest hit is the sub-Saharan region, where roughly two thirds of infections have occurred. South Africa, one of the developing countries in this region, is among the countries experiencing the greatest increase in HIV infections (Health Systems Development Unit 2001:3). Young people, who intend joining the nursing profession in South Africa and those already taking up nursing, will have to face numerous challenges caused by the increasing number of HIV infected patients.

With the HIV/AIDS pandemic continuing into its third decade, nurses need knowledge and skills to ensure not only safe patient care but also safe professional conduct. Education programmes need to focus on preparing nurses and other healthcare professionals to efficiently and competently care for HIV/AIDS patients without putting themselves at risk of contagion (Olayinka \& Osho 1997:554).

According to Siegel, Lazarus, Krasnovsky, Durbin and Chesney (1991:160), several studies have assessed AIDS-related knowledge, attitudes and behaviour among high school students, as patterns of sexual activity and experimentation with drugs frequently occur among this group and put them at risk of contracting the disease. Results of these studies indicated that the need for AIDS prevention is all too apparent, and that support is growing among adolescents for AIDS education programmes that give particular attention to emotions and anxiety relating to sexual activity. Anxiety, fear of contagion and discomfort are also experienced by undergraduate nursing students, some of whom being in the same age group as high school students. In casual conversations, nursing students also expressed fear of becoming infected with the AIDS virus while caring for patients with HIV/AIDS.

Discomfort displayed by students caring for patients with HIV/AIDS is also observed in healthcare professionals who have more knowledge and experience of managing patients. Healthcare professionals caring for HIV/ AIDS patients demonstrate a considerable amount of burnout and frustration, as they have to deal with profound physical and mental deterioration and their own feelings of helplessness (Demmer 2000: 119). These professionals are supposed to act as mentors in their practical settings and teach less experienced students the correct behaviour. Thus, their attitudes and conduct could be one reason why student nurses also have such fear and uncertainty about contracting the disease.

The results of this study could assist in understanding the views of undergraduate nursing students on caring for patients with HIV/AIDS and, ultimately, lead to an improvement in the quality of care given by these students to patients suffering from HIV/AIDS.

\section{Problem statement}

The high incidence of HIV infections in South Africa and ever-increasing numbers of HIV/AIDS patients require a great deal of knowledge and competence in the nursing profession.

Specific problems are encountered by clinical preceptors who supervise student nurses caring for HIV/AIDS patients. The most common problems are the high rate of absenteeism and lack of interest. It seems that student nurses report sick more frequently when caring for patients with HIV/AIDS than when allocated other areas of care. Similar reports are also received from professional nurses supervising students in the units. Currently limited documentation is available on the views (including opinions, beliefs and attitudes) of undergraduate nursing students on caring for patients with HIV/AIDS in South Africa.

\section{Purpose of the study}

The purpose of the study was to explore and describe the views of undergraduate nursing students on caring for patients with HIV/AIDS

\section{Research question}

The central research question was as follows: 
What are the views of undergraduate nursing students on caring for patients with HIV/AIDS?

\section{Objectives of the study}

The objectives of the study were to:

- $\quad$ Explore and describe the views of undergraduate nursing students on caring for HIV/ AIDS patients and to obtain useful information in this regard.

- Make recommendations on the coverage of HIV/AIDS in the undergraduate nursing curriculum.

\section{Research design and method}

A qualitative, exploratory and descriptive research design was used for this study.

\section{Population and sampling}

A study population involves individuals who possess certain characteristics, or a set of entities in which measurements of interest to the researcher are present (De Vos 2002:198). It refers to the entire population that meets the sampling criteria, i.e. the sum total of all cases that meet the definition of a unit of analysis (Brink \& Wood 1989:161; Uys \& Basson 1999:51)

The study population for this research consisted of all third-year students studying for the baccalaureate BCur at the Medical University of Southern Africa (Medunsa). BCur III students were chosen for the following reasons:

- They were accessible to the researcher

- $\quad$ They were better suited to the discussions on HIV/AIDS than first-year or second-year students, as they had more knowledge and experience.

- If issues were raised that needed their response, they would still be in the course the following year and would be readily available. Even after they had left the institution, which would be the year after, they would still use it as reference and the institution would still have their residential and postal addresses.

Sampling involves selecting a group of people, events, behaviour or other elements with which to conduct the study (Burns \& Grove 2001:365). It is the process of selecting a portion of the population of interest to the researcher, which conforms to a designated set of specifications (De Vos 2002:199).

The participants in this study were purposively sampled. Purposive sampling is sometimes referred to as judgmental sampling, as it involves the conscious selection by the researcher of subjects to be included in the study. Subjects are sometimes known as key informants because they are selected for their unique view on the subject at hand (Reid 1996 in Mabuza 2001:31; Wood 1992:2822). BCur III students were purposively selected for this study because of their knowledge and experience of caring for patients with HIV/ AIDS which is better than that of first and second year students.

\section{Data collection}

Data were collected from sampled undergraduate BCur III nursing students and focus group interviews were used as data collection instrument. A focus group interview is a carefully planned discussion designed to obtain perceptions on a defined area of interest in a permissive, non-threatening environment. It is a research technique that collects data through focus group interaction on a topic determined by the researcher and is an effective means for bettering understanding of how people feel or think about an issue, product or service (De Vos 2002:305).

BCur III nursing students were selected because they had certain characteristics in common concerning the topic, i.e. knowledge about caring for HIV/AIDS patients. A focus group interview is an effective technique for exploring the views of staff (Kitzinger 1995:299), and therefore it was appropriate to apply this technique to explore the views of these students. The services of a skilled group moderator were enlisted to facilitate the focus group interviews and thus overcome most of the limitations of focus group interviews whilst the researcher, took the field notes.

According to De Vos (2002:311), the optimal number of participants for a focus group interview is five to ten, but Kitzinger (1995:300) allows a number in the range of six to twelve, depending on the study's aim. Deciding on the right number of participants means striking a balance between having enough members to generate a discussion, but not having so many people that some feel crowded out (De Vos 2002:311). In this study, two groups of six members each, both males and females, were interviewed. These numbers have shown to be suitable, as both groups generated meaningful discussions without letting individuals feel inhibited or excluded.

\section{Ethical considerations}

Permission to conduct the study was obtained from Medunsa and the Ethics Committee of the University of Pretoria's Faculty of Health Sciences. Consent was also obtained from participants.

The ethical principles, as set out by Polit, Beck and Hungler (2001:74), were considered. Participants were informed that participation was voluntary, that non-participation would not compromise their student status and that they had the right to withdraw at any stage of the research study without stating reasons. Participants were not exposed to any risk or harm, as the study did not involve issues such as the administration of drugs or the performance of procedures. Instead, students could benefit from participating in the study because the research topic involved a subject covered in the BCur curriculum. Participants were treated as autonomous agents, capable of controlling their own activities and destinies. They were treated fairly and their privacy was maintained. Promises made to subjects about confidentiality were kept. The researcher ensured that no names were used and data were kept safe at all times.

The study's background, its purpose, objectives and methodology, the ethical considerations and the reporting system were explained to the participants. The explanation was followed up by an information leaflet that further explained what the study entailed, including the role of the participants. Participants were encouraged to ask questions in order to clarify issues.

\section{Data analysis}

Tesch's method of qualitative analysis, as interpreted by Cresswell (1994:155), was followed in order to analyse the transcribed data.

The researcher achieved a sense of the 
whole by listening to the audiotapes and by reading and re-reading the verbatim transcriptions. The researcher read through the transcription of the first focus group interview, read through it again and underlined the themes that emerged. The researcher applied the same procedure to the second focus group interview transcription in order to identify the themes that related to the central research question.

The coding of data was performed step by step. Repetitive words, phrases and concepts were recognised as themes. The themes were listed, and similar themes were clustered together to form subcategories. From the subcategories major categories emerged. The data units were then grouped into themes, subcategories and categories.

Data belonging to each category were assembled and a preliminary analysis was performed. The researcher enlisted the help of an independent co-coder, and both the co-coder and the researcher completed an independent analysis. The co-coder and the researcher then held a consensus meeting to clarify discrepancies and identify similarities (Coffey \& Atkins 1996:46; Creswell 1994:154).

Strategies proposed by Lincoln and Guba (1985:218) were used to establish the trustworthiness of the study. These strategies include credibility, transferability, dependability, and confirmability. (SeeTable1.)

\section{Discussion of results and literature control}

The categories, subcategories and themes portraying and conveying the views of undergraduate nursing students on caring for patients with HIV/AIDS, as they emerged during the data analysis, are displayed in Table 2. Four main categories were identified, namely emotions, needs, demands, and solutions.

\section{Category 1: Emotions}

The first category identified was 'emotions'. Several themes denoting emotions of undergraduate nursing students emerged from the data and were subcategorised into 'emotions towards self', 'emotions towards HIV/AIDS patients', 'emotions towards hospital nursing personnel' and 'emotions towards their lecturers'.

\section{Emotions of undergraduate nursing students towards self}

Within this subcategory, the themes 'fear, ignorance, guilt, hope and acceptance' emerged. Participants expressed being fearful of contracting the disease while caring for HIV/AIDS patients, and infecting other patients, or even relatives. Feelings of inadequacy and ignorance were expressed and related to their lack of knowledge about the disease. These feelings were more strongly felt when they were first-year students, especially as HIV/AIDS was not yet discussed in class. Feelings such as hope for and acceptance of HIV/AIDS patients developed as the course progressed and the condition was better understood.

Fear experienced by participants in connection with HIV/AIDS patients is congruent with a finding by Serlo and Aavarinne (1999:463) who stated that, when the condition was publicly discussed, student nurses expressed many different feelings and emotions, among others, fear, anxiety, and discomfort. The study by these researchers also revealed that this incurable disease was poorly known and prejudice ridden. Synoground and Kellmer-Langan (1991:201) indicated that student nurses expressed discomfort when caring for HIV/AIDS patients, citing inadequate preparation for dealing with these patients as one of the reasons.

\section{Emotions of undergraduate nursing students towards HIV/AIDS patients}

Participants expressed emotions such as pity and compassion towards HIV/AIDS patients but acknowledged that caring for these patients was adversely influenced by the stigma attached to the disease. Participants admitted that fear of contracting the disease caused an inability to nurse with passion. Stigmatisation resulting in unfair treatment emerged as theme from both focus group interview transcriptions. The stigma was always accompanied by discriminatory practice, while a breach of patient confidentiality surrounding HIV/ AIDS led to different forms of discrimination.

Conclusions by Jesani, Kalantri, Thomas and Srinivasan (2003: http:// www. issuesinmedicalethics.org/ $123 \mathrm{ed} 0 \mathrm{html}$ ) are in agreement with the findings above, indicating that the medical profession has extensively practised discrimination against people living with AIDS (PLWA). Discriminatory hospital practices include testing patients for HIV without their knowledge or consent, testing patients without providing pre-test counselling (contrary to national and international guidelines), and transferring private sector patients to public hospitals when these patients are found to be HIV positive.

\section{Emotions of undergraduate nursing students towards hospital nursing personnel}

Participants expressed feelings of anger towards hospital nursing personnel, stating that nursing students were expected to care for HIV/AIDS patients but were neither timeously informed about the patients' HIV/AIDS status nor given proper orientation. They also expressed frustration, as they were assigned nursing duties, such as bed bathing HIV/AIDS patients, without being orientated or supervised. Peate, Suominen, Välimäki, Lohrman and Muinonen (2002:493) reported that, in order for educationalists to address knowledge deficiencies among student nurses, it was important to assess nurses' understanding of sexually transmitted diseases (STDs) and HIV/AIDS. This aspect especially relates to the planning of curricula. Nurses need a sound understanding of the causes of HIV/ AIDS if effective quality care were to be rendered.

\section{Emotions of undergraduate nursing students towards lecturers}

Participants expressed feelings of dissatisfaction towards lecturers. The study revealed that students were dissatisfied about the lack of support from lecturers. Students who were fearful of contracting HIV/AIDS while caring for HIV/AIDS patients felt that they did not receive adequate accompaniment or counselling.

Peate et al. (2002:492) confirmed that it was important to provide education about HIV/AIDS and support student nurses who were afraid of contracting the disease while performing nursing tasks. Nurse educators act as role models for nursing students. Their clinical accompaniment of students caring for patients with HIV/AIDS, their interaction with these patients, and the degree of comfort with which they clinically supervise students caring for HIV/AIDS 


\begin{tabular}{|c|c|c|}
\hline STRATEGIES & CRITERIA & APPLICATION \\
\hline \multirow[t]{7}{*}{ Credibility } & Central research question & $\begin{array}{l}\text { - The central research question } \\
\text { was well structured and } \\
\text { explained to participants. } \\
\text { The same question was put to } \\
\text { all participants. }\end{array}$ \\
\hline & Member checking & $\begin{array}{l}\text { - } \quad \text { Follow-up interviews were } \\
\text { conducted to validate the data. }\end{array}$ \\
\hline & Prolonged engagement & $\begin{array}{l}\text { Ample time was spent with } \\
\text { participants to ensure } \\
\text { comprehension of the research } \\
\text { question. }\end{array}$ \\
\hline & Peer examination & $\begin{array}{l}\text { The services of an independent } \\
\text { co-coder were enlisted. } \\
\text { The research process was } \\
\text { discussed with experts. }\end{array}$ \\
\hline & Authority of researcher and moderator & $\begin{array}{l}\text { - The researcher is trained in } \\
\text { community health care and } \\
\text { primary health care, and is a } \\
\text { trained nurse educator with } \\
\text { teaching experience. She has } \\
\text { completed coursework for the } \\
\text { master's degree in community } \\
\text { health nursing. } \\
\text { The group moderator is a } \\
\text { trained psychiatric nurse and } \\
\text { an experienced focus group } \\
\text { interviewer with interviewing } \\
\text { and counselling skills. She had } \\
\text { completed a course in } \\
\text { qualitative research and } \\
\text { supervised many postgraduate } \\
\text { research studies at Medunsa. }\end{array}$ \\
\hline & Structural coherence & $\begin{array}{l}\text { The interviews focused on only } \\
\text { the views of undergraduate } \\
\text { nursing students. } \\
\text { Asking the same question } \\
\text { prevented inconsistencies. } \\
\text { The exact meanings of key } \\
\text { terms were described. }\end{array}$ \\
\hline & Dense descriptions & $\begin{array}{l}\text { Dense descriptions were given } \\
\text { of the methodology and the } \\
\text { results. The results included } \\
\text { verbatim quotations. }\end{array}$ \\
\hline
\end{tabular}




\begin{tabular}{|c|c|c|}
\hline & $\begin{array}{l}\text { Authority of participants } \\
\text { (Nominated sample) }\end{array}$ & $\begin{array}{l}\text { The participants were } \\
\text { representative of the study } \\
\text { population. BCur III students } \\
\text { were selected for their } \\
\text { knowledge and experience of } \\
\text { caring for HIV/AIDS patients. }\end{array}$ \\
\hline Dependability & Dense description of methodology & $\begin{array}{l}\text { Well-defined results followed a } \\
\text { dense description of the } \\
\text { research methodology, data } \\
\text { gathering, data analysis and } \\
\text { interpretation. } \\
\text { During data analysis, a code- } \\
\text { recode procedure was followed } \\
\text { and results were compared. }\end{array}$ \\
\hline \multirow[t]{3}{*}{ Confirmability } & Confirmability audit & $\begin{array}{l}\text { That could be done, as all } \\
\text { records of data collection and } \\
\text { analysis were kept. }\end{array}$ \\
\hline & Researcher objectivity & $\begin{array}{l}\text { The researcher strived to } \\
\text { remain objective throughout } \\
\text { the study. } \\
\text { Researcher-imposed ideas } \\
\text { during data collection were } \\
\text { carefully guarded against, inter } \\
\text { alia by enlisting the services } \\
\text { of a professional group } \\
\text { moderator. }\end{array}$ \\
\hline & $\begin{array}{l}\text { Audit trial } \\
\text { (Authority of the supervisor and } \\
\text { involvement of other researchers) }\end{array}$ & $\begin{array}{l}\text { The supervisor guided and } \\
\text { monitored the researcher's } \\
\text { work. } \\
\text { Other researchers were allowed } \\
\text { to audit the study. } \\
\text { Records were made available to } \\
\text { the supervisor for scrutiny. }\end{array}$ \\
\hline
\end{tabular}

(De Vos 2002:351; Lincoln \& Guba 1985:218.)

patients determine the impact that the disease has on the quality of nursing care (Durkin 2003:129).

\section{Category 2: Needs}

Within the second main category, three subcategories were identified, namely: 'needs identified with reference to undergraduate nursing students, healthcare professionals, and the general public'.

\section{Needs identified with reference to undergraduate nursing students}

While expressing their views on caring for patients with HIV/AIDS, nursing students identified needs relating to 'knowledge and education', 'support and counselling' and 'curriculum innovation'.
They expressed the opinion that a module on HIV/AIDS should be included in the undergraduate nursing curriculum at firstyear level, emphasising curriculum innovation in this regard as a matter of urgency. Participants' need for curriculum innovation is supported by Petro-Nustas (2000:433) who stated that there was a need for introducing a tailor-made course on HIV/AIDS, to be offered to students as part of their study plans/curricula. This is in accordance with findings by Snowden (1997:1167) who stated that nursing education programmes should be modified to have a greater impact on HIV/ AIDS.

\section{Needs identified with reference to healthcare professionals}

Within the subcategory "needs identified with reference to healthcare professionals', the themes 'knowledge and education' and 'reducing stigmatisation' were identified during the coding process. Participants expressed the need for healthcare professionals to be educated about HIV/AIDS, because these professionals did not have the most recent information about the disease and were unable to clearly explain or motivate nursing actions towards HIV/AIDS patients, causing confusion among nursing students. According to the participants, health professionals should take action to reduce the stigma associated with HIV/ AIDS and, in order for these professionals to change their negative 


\begin{tabular}{|c|c|c|c|}
\hline \multirow[t]{4}{*}{$\begin{array}{l}\text { CATEGORIES } \\
\text { 2.1 EMOTIONS } \\
\text { (of undergraduate nursing students) }\end{array}$} & $\begin{array}{l}\text { SUBCATEGORIES } \\
\text { 2.1.1 Towards self }\end{array}$ & \multicolumn{2}{|c|}{$\begin{array}{ll}\text { THEMES } \\
\text { a. } & \text { Fear } \\
\text { b. } & \text { Ignorance } \\
\text { c. } & \text { Guilt } \\
\text { d. } & \text { Hope and acceptance }\end{array}$} \\
\hline & 2.1.2 Towards HIV/AIDS patients & $\begin{array}{l}\text { a. } \\
\text { b. }\end{array}$ & $\begin{array}{l}\text { Pity and compassion } \\
\text { Stigma }\end{array}$ \\
\hline & 2.1.3 Towards hospital nursing personnel & a. & Anger and frustration \\
\hline & 2.1.4 Towards their lecturers & a. & Dissatisfaction \\
\hline \multirow[t]{3}{*}{$\begin{array}{l}\text { 2.2 NEEDS IDENTIFIED } \\
\text { (with reference to) }\end{array}$} & 2.2.1 Undergraduate nursing students & $\begin{array}{l}\text { a. } \\
\text { b. } \\
\text { c. }\end{array}$ & $\begin{array}{l}\text { Education and knowledge } \\
\text { Support and counselling } \\
\text { Curriculum innovation }\end{array}$ \\
\hline & 2.2.2 Healthcare professionals & $\begin{array}{l}\text { a. } \\
\text { b. }\end{array}$ & $\begin{array}{l}\text { Knowledge and education } \\
\text { Reducing the stigma }\end{array}$ \\
\hline & 2.2.3 The public & $\begin{array}{l}\text { a. } \\
\text { b. }\end{array}$ & $\begin{array}{l}\text { Knowledge and education } \\
\text { Support }\end{array}$ \\
\hline \multirow{3}{*}{$\begin{array}{l}\text { 2.3 DEMANDS DIRECTED } \\
\text { (at) }\end{array}$} & 2.3.1 Healthcare professionals & a. & Recognition of 'student status' \\
\hline & 2.3.2 Lecturers & a. & $\begin{array}{l}\text { Intensive clinical accom- } \\
\text { paniment }\end{array}$ \\
\hline & 2.3.3 Government & a. & Antiretroviral therapy delivery \\
\hline \multirow[t]{3}{*}{$\begin{array}{l}2.4 \text { SOLUTIONS } \\
\text { (involving) }\end{array}$} & 2.4.1 Undergraduate nursing students & a. & $\begin{array}{l}\text { Student participation in } \\
\text { prevention campaigns }\end{array}$ \\
\hline & 2.4.2 HIV/AIDS patients & $\begin{array}{l}\text { a. } \\
\text { b. }\end{array}$ & $\begin{array}{l}\text { Universality of care } \\
\text { Patients' rights }\end{array}$ \\
\hline & 2.4.3 Community and government & a. & $\begin{array}{l}\text { Reducing the stigma and giving } \\
\text { support }\end{array}$ \\
\hline
\end{tabular}

attitudes and discriminatory behaviour towards HIV/AIDS patients, they have to be educated.

Stewart (1999:741) confirmed that health professionals showed negative attitudes and discriminative behaviour. Among other things, the author referred to high levels of homophobia among doctors and nurses, and avoidance and stigmatising behaviour by physicians and dentists towards patients with HIV/AIDS.

Jesani et al. (2003: http:// www.issuesinmedicalethics.org/ $123 \mathrm{ed} 0 . \mathrm{html}$ ) attested to these facts, stating that, in public hospitals, patients with HIV infection were referred to the STD wards, regardless of the source of infection, denied emergency treatment, or were isolated, thus making their HIV status known.

\section{Needs identified with reference to the public}

'Knowledge and education' and 'support' were identified as themes within this subcategory. Participants indicated that knowledge of and education about HIV/AIDS should extend to the general public, communities included, as most HIV/AIDS patients receive home-based care. Knowledge and education would empower the public to better support HIV/AIDS patients and their families. As expressed by the participants, support could take the form of active involvement in church and community organisations caring for these patients. According to the participants, the South African government should take a greater responsibility for educating the public and ensuring community support for HIV/AIDS patients and their families.

The need for a general public that is knowledgeable about HIV/AIDS and supportive of HIV/AIDS patients and the government's responsibility in this regard were also emphasised in a study by Uwakwe (2000:423) about systemised HIV/AIDS education for student nurses. Uwakwe stated that the relative reluctance of Nigerian healthcare workers to treat HIV/AIDS patients was not only attributable to erroneous attitudes and beliefs, but also due to a shortage of 
health supplies, such as syringes and gloves, that were needed to comply with universal precautions. Health departments or health ministries are responsible for providing health education and supplying adequate health resources, including facilities and supplies.

\section{Category 3: Demands}

Participants directed demands at healthcare professionals, lecturers and the government.

\section{Demands directed at healthcare professionals}

'Recognition of student status' emerged as theme under this subcategory. Participants indicated that they did not wish to be regarded as additional staff members in the wards but as student nurses. In addition, they demanded freedom of expression in clinical practice, especially when caring for HIV/AIDS patients. Participants explained that the non-communicative practice of referring the patient to the doctor every time the patient requests information about her/ his condition was a barrier towards the successful delivery of care. Furthermore, participants argued that nurses, including student nurses, who attended to the patient by staying at her/his bedside most of the time, should be given some freedom of expression to be able to deal with the patient's health issues.

Research by Arhin and Johnson-Mallard (2003:121-2), describing students' needs for independence and self-expression, supports the demand for recognition of student status expressed by participants in this study. Arhin and Johnson-Mallard described the majority of students in classrooms of colleges and universities today as "products of a generation of latchkey kids', who grew up with daycare, television and computers as surrogate parents and the proliferation of technology, the Internet and cellphones, which made them independent and resource conditioned. Students, therefore, are a challenge for educators, and need to be encouraged, and given alternative forms of self-expression.

\section{Demands directed at lecturers}

Under this subcategory, the theme 'clinical accompaniment' emerged, as almost all participants in the study strongly urged more intensive clinical accompaniment by lecturers, especially in the first study year when they were unsure and fearful of patients infected with the AIDS virus. The quality of clinical accompaniment of students is an important dimension of the education or learning programme. Clinical preceptors/ mentors are responsible for ensuring students' compliance with the clinical outcomes of the programme, in accordance with requirements laid down by the nursing education institution and the South African Nursing Council (Tsele \& Muller 2000:33).

\section{Demands directed at government}

Participants expressed the importance of antiretroviral therapy delivery by government. De Martino, Tovo, Balducci, Galli, Gabiano, Rezza and Pezzotti (2000: 2871-2) confirm the importance of antiretroviral therapy, stating that since the introduction of combined antiretroviral therapy in Italy, mortality rates in adults with HIV Type 1 infection have decreased.

\section{Category 4: Solutions}

Within the final category 'solutions', three subcategories emerged, namely: 'solutions involving undergraduate nursing students', 'solutions involving HIV/AIDS patients', and 'solutions involving communities and government'.

\section{Solutions involving undergraduate nursing students}

'Students participating in prevention campaigns' emerged as theme within this subcategory. Participants felt that student nurses should actively rally community support for HIV/AIDS patients and their families.

On the organisation Advocates for Youth's homepage, My Voice Counts (2005: http://www.advocatesforyouth. org/youth/advocacy/myvoicecounts/ globalhiv/), it is stated that under Uganda's successful ABC strategy (Abstinence, Be faithful, use Condoms), everyone was encouraged to adopt abstinence, if appropriate, be faithful to one partner, and use condoms. Contrary to this, under the US President's Emergency Plan for AIDS Relief, these messages were separated and directed at different groups - abstinence was intended for only young people; be faithful, for only married couples; and use condoms, for only sex workers and others who were considered being at great risk of contracting the disease.

Solutions involving HIV/AIDS patients

Within this subcategory, two themes emerged, namely 'universality of care' and 'patients' rights'.

Participants argued that patients should not be treated differently because of their HIV/AIDS status. They proposed that healthcare professionals should reorientate themselves towards applying a holistic healthcare strategy, as opposed to following a purely physical healthcare approach. In this study, HIV/AIDS patients were seen as having rights equal to all other patients, as stipulated by the Patients' Bill of Rights.

The proverb 'actions speak louder than words' is especially applicable to crosscultural communication (Williams \& Davis 2004:58). Williams and Davis emphasise the importance of crosscultural non-verbal communication and state that nurses have to be extra careful when caring for patients of diverse cultures. This applies to South African nurses, as South Africa is a multicultural country. Whatever caring modality is used, nurses should ensure that their strategies of caring are universally acceptable to the recipients of care.

\section{Solutions involving communities and government}

The discussions of participants focused on reducing stigma and increasing support for HIV/AIDS patients and their families. In this study, government was seen as having a responsibility, in partnership with communities, to reduce the stigma attached to HIV/AIDS. This could be accomplished by implementing awareness programmes among communities that patients with HIV/AIDS are like all other patients with chronic diseases.

Uys and Cameron (2003:81) indicate that a holistic continuum of HIV prevention, support and care structures is needed to prevent the stigmatisation, discrimination and trauma associated with HIV/AIDS. Informal social structures made up of family, friends and neighbours often offer care and support to individuals in their own homes, that is, community-based home care. However, home-based caregivers need additional support from outside their immediate circle.

\section{Recommendations}

The following recommendations are based on the above findings and problems identified in the study.

- $\quad$ Students should actively 
participate in HIV/AIDS prevention campaigns. This finding/recommendation challenges not only the Medunsa Nursing Science Department but all other nursing science departments at universities and colleges to involve students in organising and undertaking such campaigns.

In order to mobilise community support, HIV/AIDS patients and their families should be involved in community projects geared towards the fight against the disease. This way, HIV/AIDS patients will gain acceptance by their families and communities.

- $\quad$ Regular in-service training programmes and workshops should be conducted at all healthcare settings, including those in communities, in order to update healthcare personnel and communities on the latest developments regarding HIV/ AIDS.

- $\quad$ Rather than seeing them as extra workforce, healthcare professionals (especially nursing staff) should support nursing students in clinical practice areas and recognise their student status.

- The South African government should take responsibility for intensifying antiretroviral therapy delivery, particularly to outreach centres servicing rural communities. The government should ensure that HIV/AIDS patients receive the support they need in the form of social grants and the training of informal caregivers.

In order to accommodate a module on HIV/AIDS at firstyear level, nursing science departments at universities and colleges should urgently consider curriculum innovation.

\section{Conclusion}

HIV infection and AIDS are having considerable effects on the healthcare system in South Africa. It is important that student nurses should be supported in caring for HIV/AIDS patients. This study will help educationalists plan and implement programmes that are sensitive to the needs of not only students, but also HIV/AIDS patients and their families, thereby improving the quality of care provided for HIV/AIDS patients and ensuring support of their families. [4313 words]

\section{References}

ARHIN,AO \& JOHNSON-MALIARD, V 2003: Encouraging alternative forms of self-expression in the generation of young students: A strategy for effective learning in the classroom. The ABNF Journal. 14(6): 121-2.

BRINK, JB \& WOOD, MJ 1989: Advanced designs in nursing research. $2^{\text {nd }}$ edition. Thousand Oaks: Sage.

BURNS, N \& GROVE, SK. 2001. The practice of nursing research: Conduct, critique $\&$ utilization. $4^{\text {th }}$ edition. Philadelphia: Saunders.

COFFEY, A \& ATKINS, P 1996: Making sense of qualitative data: Complementary research. Thousand Oaks: Sage.

CRESSWELL, JW 1994: Research design: Qualitative \& quantitative approaches. Thousand Oaks: Sage.

DE MARTINO, M; TOVO, PA; BALDUCCI, M; GALLI,L; GABIANO, C; REZZA, G \& PEZZOTTI, P 2000: Reduction in mortality with availability of antiretroviral therapy for children with perinatal HIV-1 infection. Italian Register 1. HIV infection in children and the Italian National AIDS Register. Journal of American Medical Association. 284(22): 2871-2.

DEMMER, C 2000: The relationship between death related experiences, death anxiety and patient care attitudes among AIDS nursing staff. Journal for Nurses in Staff Development. 16(3): 118-23

DE VOS, AS 2002: Research at grass roots - For the social science and human service professions. $2^{\text {nd }}$ edition. Pretoria: Van Schaik.

DURKIN, A 2003: Comfort levels of faculty regarding student assignment to a patient with AIDS. Nurse Education in Practice, 3:124-32.

EVIAN, C 2000: Primary AIDS care. A practical guide for primary healthcare personnel in the clinical and supportive care of people with HIV/AIDS. $3^{\text {rd }}$ edition. Johannesburg: Jacana Education.
HEALTHSYSTEMS DEVELOPMENT

UNIT 2001: Primary clinical care, vol. 3. Sandown: Heinemann.

JESANI,A; KALANTRI,SP; THOMAS, G \& SRINIVASAN, S 2003: Government-funded antiretroviral therapy for HIV/AIDS: New clinical challenges. Indian Journal of Medical Ethics [Online].

http://www.issuesinmedicalethics.org/ 123ed0.html [Accessed: 16 February 2005].

KITZINGER, J 1995: Qualitative research: Introducing focus groups. British Medical Journal. 31 1: 299-302.

LINCOLN, S \& GUBA, E 1985: Naturalistic inquiry. London: Sage.

MABUZA, LH 2001: A qualitative assessment of the family. Functioning of suicide victims in Mutsulu Township, Mpumalanga. Pretoria: Medical University of Southern Africa.

MY VOICE COUNTS [Homepage of Advocates for Youth] [Online] 2005: Global HIV prevention campaign - Stop US exportation of abstinence-only programs.

http://www.advocatesforyouth.org/ youth/advocacy/myvoicecounts/ globalhiv/ [Accessed: 16 February 2005].

OLAYINKA, BA \& OSHO, AA 1997: Changes in attitudes, sexual behaviour and the risk of HIV/AIDS transmission in south-west Nigeria. East African Medical Journal, 74(9): 554-60.

PEATE, I; SUOMINEN, T; VÄI IMÄKI. M; LOHRMAN, C \& MUINONEN, U 2002: HIV/AIDS and its impact on student nurses. Nurse Education Today. 22(6): 492-501.

PETRO-NUSTAS, W 2000: University students' knowledge of AIDS. International Journal of Nursing. 37(5): 423-33.

POLIT, DF; BECK, CT \& HUNGLER, BP 2001: Essentials of nursing research. Methods, appraisals and utilization. $5^{\text {th }}$ edition. Philadelphia: Lippincott.

SERLO, KL \& AAVARINNE, H 1999: Attitudes of university students towards HIV/AIDS. Journal of Advanced Nursing. 29(2): 463-70.

SIEGEL， D; LAZARUS， N; 
KRASNOVSKY, F; DURBIN, M \&

CHESNEY, M 1991: Aids - Knowledge, attitudes, behaviour among inner city, junior high school students. Journal of School Health. 61(4): 160-5.

SNOWDEN, L 1997. An investigation into whether nursing students alter their attitudes and knowledge level regarding HIV infection and AIDS following a 3year programme leading to registration as a qualified nurse. Journal of Advanced Nursing. 25:1167-74.

STEWART, D 1999: The attitudes and attributions of student nurses: Do they alter according to a person's diagnosis or sexuality and what is the effect of nurse training? Journal of Advanced Nursing. 30(3): $740-8$.

SYNOGROUND, SL \& KELLMERLANGAN, DM 1991: Nursing students' attitudes towards AIDS: Implication for education. Nurse Education Today. 11(3): 200-206.

TSELE, N \& MULLER, M 2000: Clinical accompaniment: The critical care nursing students' experiences in private hospital. Curationis. 23(2): 32-6.

UWAKWE, CBU 2000: Systemized HIV/ AIDS education for student nurses at University of Ibada, Nigeria: Impact on knowledge, attitudes and compliance with universal precautions. Journal of Advanced Nursing. 32(2): 416-24.

UYS, HNM \& BASSON, AA 1999: Research methodology in nursing. Pretoria: Kagiso Tertiary.

UYS, L \& CAMERON, C 2003: Homebased HIV/AIDS care. Cape Town: Oxford University Press.

WILLIAMS, C \& DAVIS, C 2004: Therapeutic interaction in nursing. Thorofare: Slack Incorporated.

WOOD, ML 1992. Focus group interview in family practice. Canadian Family Physician. 38: 2821-7. 